\title{
Arbuscular mycorrhizal fungal communities and soil organic matter in pasture and analog agroforestry systems
}

\author{
Cristiane Figueira da Silva ${ }^{1} \oplus$, Rodrigo Camara ${ }^{1} \oplus$, Marcos Gervasio Pereira ${ }^{1 *} \odot$, Gilsonley Lopes dos Santos ${ }^{1} \odot$, \\ Gabriel Santos Aguiar ${ }^{1} \odot$, Camila Santos da Silva ${ }^{1} \oplus$, Hugo de Souza Fagundes ${ }^{1} \oplus$, Eliane Maria Ribeiro da Silva ${ }^{2}$

\footnotetext{
1 Universidade Federal Rural do Rio de Janeiro, Seropédica, RJ, Brasil. E-mail: cfigueirasilva@yahoo.com.br; rcamara73@gmail.com; mgervasiopereira@gmail.com; leylopes85@hotmail.com; gabriel.bio12@yahoo.com.br; milasdas@gmail.com; hugofagundes90@gmail.com

${ }^{2}$ Embrapa Agrobiologia, Seropédica, RJ, Brasil. E-mail: eliane.silva@embrapa.br
}

ABSTRACT: Study aimed to (i) assess the impact of analog agroforestry (agrofor) on arbuscular mycorrhizal fungi (AMF), easily extractable glomalin-related soil protein (EE-GRSP), soil organic matter (SOM), and aggregate stability compared with a pasture system and (ii) investigate the chemical, physical and OM properties that explain the differences in soil microbiology between sites. The study was conducted in an agrofor and pasture area. Soil samples were collected in the dry season. A total of 12 AMF taxa were identified. Mean richness was positively correlated with soil pH, $\mathrm{Mg}^{2+}$, sum of bases (SB) and moisture. Mean richness and diversity were higher in the analog agroforestry site. Pasture soil had higher EE-GRSP content and spore abundance, variables that were found to be positively correlated with soil temperature, $\mathrm{P}, \mathrm{K}^{+}$, and $\mathrm{H}+\mathrm{Al}$. EE-GRSP also showed a positive correlation with total organic carbon. Aggregate stability was greater in soil under analog agroforest than pasture. SOM properties did not differ between sites. It is concluded that agrofor changes the evaluated soil physical and microbiological attributes, and the microbiological attributes are influenced by the $\mathrm{pH}, \mathrm{Mg}^{+2}, \mathrm{~K}^{+}, \mathrm{SB}, \mathrm{P}, \mathrm{H}+\mathrm{Al}$, soil moisture and TOC.

Key words: glomalin; light-fraction organic matter; organic carbon fraction; weighted mean diameter

\section{Fungos micorrízicos arbusculares e matéria orgânica do solo em sistema agroflorestal regenerativo análogo e pastagem}

RESUMO: O estudo objetivou avaliar o impacto de um sistema agroflorestal regenerativo análogo (SAFRA) na comunidade de fungos micorrízicos arbusculares (FMAs), na proteína do solo relacionada à glomalina - facilmente extraível (PSRG-FE), na matéria orgânica (MO) e na estabilidade de agregados comparado a uma área de pastagem. Além disso, avaliar as propriedades químicas, físicas e da MO que explicam a variação dos atributos microbiológicos do solo em tais áreas. 0 estudo foi conduzido em uma área de SAFRA e de pastagem. As amostras de solo foram coletadas na estação seca. Foram identificados 12 taxas de FMAs. A riqueza média (RM), correlacionou-se positivamente com o pH, $\mathrm{Mg}^{2+}$, soma de bases (SB) e umidade do solo. Tanto a riqueza média quanto a diversidade foram maiores no SAFRA. Na pastagem, foram maiores a abundância de esporos (AE) e PSRG-FE, sendo que ambas as variáveis se correlacionaram positivamente com a temperatura do solo, $\mathrm{P}, \mathrm{K}^{+}$e H+Al. A PSRGFE também se correlacionou positivamente com o carbono orgânico total. A estabilidade de agregados foi maior no SAFRA, e os atributos da MO não variaram entre as áreas. Conclui-se que o SAFRA altera os atributos físicos e microbiológicos avaliados, e os atributos microbiológicos são influenciados pelo $\mathrm{pH}, \mathrm{Mg}^{+2}, \mathrm{~K}^{+}, \mathrm{SB}, \mathrm{P}, \mathrm{H}+\mathrm{Al}$, umidade do solo e COT.

Palavras-chave: glomalina; matéria orgânica leve; frações do carbono orgânico; diâmetro médio ponderado

\footnotetext{
* Marcos Gervásio Pereira - E-mail: mgervasiopereira@gmail.com (Corresponding author)

Associate Editor: Mário de Andrade Lira Júnior
} 


\section{Introduction}

Analog agroforestry systems, in which the horizontal and vertical stratification of the plant community follows the structure of a natural forest, contribute to the recovery of degraded Atlantic Forest fragments within four years of implementation (Souza \& Piña-Rodrigues, 2013). These systems aim to restore environmental functions and increase biodiversity and agricultural and forest productivity (Souza et al., 2016). A recent investigation showed that, in comparison with pasture systems, analog agroforests not only enhance soil fertility, but also the complexity of the soil faunal community, as evidenced by an increase in the total abundance, mean and total richness, evenness, and diversity of soil taxa (Camara et al., 2020). However, few studies have examined the influence of natural succession in analog agroforestry systems on soil organic matter fractions, aggregate stability, arbuscular mycorrhizal fungi (AMF) (Martins et al., 2019), and easily extractable glomalin-related soil protein (EE-GRSP).

AMF play an important role in forest regeneration, with root colonization intensity and soil spore density progressively decreasing during ecological succession from pasture to mature forest (Zangaro et al., 2012). There is a possible positive relationship between AMF richness and plant species composition in different environments during ecological succession. The beneficial action of AMF on soil aggregation may be the result of glomalin production and particle approximation by external mycelia (Liu et al., 2020). Glomalin is a glycoprotein with well-described cementing effects on soil aggregates. AMF respond to changes in land use and promote carbon sequestration via GRSP, which represents 4 to $5 \%$ of the soil carbon stock (Singh et al., 2017). These observations demonstrate that AMF are important components of the soil biota and have great value as biological indicators of soil quality.

Soil organic matter (OM), in turn, is important in maintaining soil quality and sustainability (Costa et al., 2013). Its physical fractionation (particulate organic carbon and mineral-associated organic carbon) contributes to the acquisition of soil quality indicators, since it supports to distinguish carbon compartments subject to the influence of land use and management systems (Balin et al., 2017). OM influences the soil chemical properties, such as the supply of nutrients to plants, and the complexation of toxic elements and micronutrients. Influence also on the soil physical properties, such as aggregate stability, which in turn interfere on bulk density, porosity, aeration, water retention and infiltration, which are essential for soil productivity (Costa et al., 2013).

The purpose of this study was to evaluate the impact of an 11-year analog agroforestry system on AMF abundance and diversity and EE-GRSP content, assess the relationship of soil microbiology with soil chemical and physical properties, and determine the influence of analog agroforestry on soil organic matter and aggregate stability compared with an adjacent field of managed pasture (the former land use type of the agroforestry site).

\section{Materials and Methods}

\section{Study sites and sampling procedures}

The study was conducted at the agroecological farm of Seropédica, Rio de Janeiro State, Brazil (22 $44^{\prime} 38^{\prime \prime} \mathrm{S} 43^{\circ} 42^{\prime} 27^{\prime \prime}$ $\mathrm{W}, 26 \mathrm{~m}$ elevation). The predominant climate is of the Aw type (Köppen classification), characterized by dry winters and wet summers. The average annual precipitation is $1213 \mathrm{~mm}$, with rainfall occurring mostly between November and March, and the average annual temperature is $23.9{ }^{\circ} \mathrm{C}$. The primary vegetation is semideciduous tropical rainforest.

Two sites were selected for this investigation: a pasture on Argissolo Vermelho-Amarelo and an analog agroforest on Planossolo. The pasture site, composed of Megathyrsus maximus (syn. Panicum maximum) and Urochloa brizantha, surrounds the $6000 \mathrm{~m}^{2}(200 \times 30 \mathrm{~m})$ agroforestry system, which was established in February 2005. The agroforest was previously covered by $M$. maximus and underwent floristic changes over the years (see Martins et al., 2019). At the time of installation, the entire agroforestry site was planted with 36 tree species at a spacing of $1.0 \times 1.0 \mathrm{~m}$ in addition to the following short cycle crops and green manure species: pigeon pea (Cajanus cajan, spacing of $1.0 \times 0.3 \mathrm{~m}$ ), sunflower (Helianthus annuus, $1.0 \times 0.5 \mathrm{~m}$ ), squash (Cucurbita sp., $3.0 \times$ $3.0 \mathrm{~m}$ ), banana (Musa sp., $3.0 \times 3.0 \mathrm{~m}$ ), sugarcane (Saccharum officinarum, $3.0 \times 3.0 \mathrm{~m}$ ), pineapple (Ananas comosus, $1.0 \times$ $0.4 \mathrm{~m}$ ), and cassava (Manihot esculenta, $1.0 \times 0.5 \mathrm{~m}$ ). Tectona grandis seedlings were planted in April 2009. In January 2010, invasive grasses were removed, part of the canopy (10-15\%) was pruned, and the agroforest community was enriched with seedlings of Euterpe edulis, Apuleia leiocarpa, Erythroxylum pulchrum, Cedrela fissilis, and Plathymenia foliosa. Seedlings of Spondias sp. were planted in April 2010. Spontaneous occurrence of Eriotheca candolleana, Erythroxylum pulchrum, Anadenanthera sp., Mimosa bimucronata, and Eugenia brasiliensis was observed between April 2008 and May 2010 (Camara et al., 2020).

Data on soil physical and chemical properties and microclimate (gravimetric moisture content and soil temperature) in the $0-5 \mathrm{~cm}$ depth layer (Table 1) were previously published by the authors (Camara et al., 2020). Correlations between these parameters and the results of the present study were investigated.

Disturbed soil samples were collected for chemical, physical, and microbiological analyses in October 2016 (end of the dry season). In the 11-year analog agroforestry site, tree individuals predominated, and short-lived crops had been completely replaced by other plant species. A total of 10 composite samples were collected at a depth of $0-5 \mathrm{~cm}$ from randomly distributed points at each site. Each composite sample comprised three subsamples. The material was evaluated for particulate organic carbon and mineralassociated organic carbon (Cambardella \& Elliott, 1992), lightfraction organic matter (Anderson \& Ingram, 1989), EE-GRSP, and AMF community structure. In addition to disturbed soil samples, five discrete undisturbed samples were collected 
Table 1. Soil physical and chemical properties, total organic carbon (TOC), gravimetric moisture content $\left(\mathrm{W}_{\mathrm{g}}\right)$, and temperature $(T)$ in the $0-5 \mathrm{~cm}$ depth layer in pasture and analog forestry sites in Seropédica, Rio de Janeiro, Brazil.

\begin{tabular}{|c|c|c|c|c|c|}
\hline \multirow{2}{*}{ Site } & \multirow{2}{*}{$\begin{array}{c}W_{g} \\
\left(\mathrm{~g} \mathrm{~g}^{-1}\right)\end{array}$} & \multirow{2}{*}{$\begin{array}{c}\mathrm{T} \\
\left({ }^{\circ} \mathrm{C}\right) \\
\end{array}$} & Sand & Clay & Silt \\
\hline & & & \multicolumn{3}{|c|}{$\left(\mathrm{g} \mathrm{kg}^{-1}\right)$} \\
\hline Pasture & $4.89 \mathrm{~B}$ & $27.4 \mathrm{~A}$ & $635.7 \mathrm{~A}$ & $241.4 \mathrm{~A}$ & $122.9 \mathrm{~A}$ \\
\hline Analog agroforest & $9.98 \mathrm{~A}$ & $24.1 \mathrm{~B}$ & $700.8 \mathrm{~A}$ & $181.6 \mathrm{~A}$ & $117.6 \mathrm{~A}$ \\
\hline \multirow{2}{*}{ Site } & \multirow{2}{*}{$\begin{array}{c}\mathrm{pH} \\
\text { in } \mathrm{H}_{2} \mathrm{O}\end{array}$} & $\mathrm{Ca}^{2+}$ & $\mathrm{Mg}^{2+}$ & $\mathbf{K}^{+}$ & $\mathrm{Na}^{+}$ \\
\hline & & \multicolumn{4}{|c|}{$\left(\mathrm{cmol}_{\mathrm{c}} \mathrm{dm}^{-3}\right)$} \\
\hline Pasture & $4.25 \mathrm{~B}$ & $1.74 \mathrm{~B}$ & $1.77 \mathrm{~B}$ & $0.10 \mathrm{~A}$ & $0.02 \mathrm{~A}$ \\
\hline Analog agroforest & $5.29 \mathrm{~A}$ & $2.10 \mathrm{~A}$ & $2.35 \mathrm{~A}$ & $0.07 \mathrm{~B}$ & $0.02 \mathrm{~A}$ \\
\hline \multirow{2}{*}{ Site } & SB & $\mathrm{H}+\mathrm{Al}$ & TOC & $\mathbf{N}$ & $\mathbf{P}$ \\
\hline & \multicolumn{2}{|c|}{$\left(\mathrm{cmol}_{\mathrm{c}} \mathrm{dm}^{-3}\right)$} & \multicolumn{3}{|c|}{$\left(\mathrm{mg} \mathrm{kg}^{-1}\right)$} \\
\hline Pasture & $3.63 \mathrm{~B}$ & $9.29 \mathrm{~A}$ & $31.02 \mathrm{~A}$ & $0.42 \mathrm{~A}$ & $17.12 \mathrm{~A}$ \\
\hline Analog agroforest & $4.53 \mathrm{~A}$ & $4.74 \mathrm{~B}$ & $26.02 \mathrm{~B}$ & $0.38 \mathrm{~A}$ & $6.06 \mathrm{~B}$ \\
\hline
\end{tabular}

from the $0-5 \mathrm{~cm}$ depth layer for analysis of the weighted mean diameter of soil aggregates (Donagemma et al., 2011).

\section{Evaluation of AMF community structure}

AMF spores were extracted from $50 \mathrm{~g}$ of soil from each composite sample by wet sieving (Gerdermann \& Nilcoson, 1963), centrifugation in water, and, subsequently, centrifugation in $45 \%$ sucrose. Spores were counted in a grooved plate under a stereoscopic microscope, and species were identified under an optical microscope on the basis of morphological characteristics (Oehl et al., 2011) and data from the International Culture Collection of (Vesicular) Arbuscular Mycorrhizal Fungi website.

After AMF species identification, we calculated the mean species richness and the Margalef diversity index using the following equation: $I=[(n-1)] / I n N$, where I is the Margalef diversity index, $\mathrm{n}$ is the number of species, and $\mathrm{N}$ is the total number of individuals from all species. Then, we estimated the relative frequency of AMF species $\left(F_{i}\right)$, determined as the number of samples in which species i was identified divided by the total number of samples. Species were classified according to their dominance on the basis of $F_{\text {, values (Zhang }}$ et al., 2004), as follows: dominant $\left(F_{i}>50 \%\right)$, very common $\left(30 \%<\mathrm{F}_{i} \leq 50 \%\right)$, common $\left(10 \%<\mathrm{F}_{i} \leq 30 \%\right)$, and rare $\left(\mathrm{F}_{\mathrm{i}} \leq\right.$ $10 \%)$. The degree of similarity between AMF communities of study sites was assessed using the Sørensen index, calculated as $S=2 \mathrm{j} /(\mathrm{a}+\mathrm{b})$, where $\mathrm{j}$ is the total number of AMF species, $\mathrm{a}$ is the total number of species in the pasture site, and $b$ is the total number of species in the analog agroforestry site.

\section{Determination of GRSP}

Glomalin was quantified as GRSP. EE-GRSP was obtained by autoclave extraction $\left(121^{\circ} \mathrm{C}, 30 \mathrm{~min}\right)$ using $1 \mathrm{~g}$ of soil and $8 \mathrm{~mL}$ of $20 \mathrm{mM}$ sodium citrate solution ( $\mathrm{pH} 7.0)$. After autoclaving, the material was centrifuged at $4000 \mathrm{rpm}$ for $10 \mathrm{~min}$ and the supernatant removed. Protein quantification was carried out by the Bradford method using bovine serum albumin as standard (Wright et al., 1996). EE-GRSP concentrations were transformed to $\mathrm{mg} \mathrm{g}^{-1}$ soil considering the total supernatant volume and soil dry weight.

\section{Data analysis}

Homogeneity of variance was assessed by Levene's test. When the assumption of homoscedasticity was met, means were compared by the parametric Bonferroni test and, when not, means were compared by the nonparametric MannWhitney test. Pearson correlations were determined between replications of spore abundance, EE-GRSP, AMF richness, presence/absence of AMF species and soil physical and chemical properties and microclimate. Statistical analyses were performed using Statistica version 8.0. Significance was set at $p<0.05$. All variables, except weighted mean diameter (which had a different number of replications), were subjected to principal component analysis using PAST version 2.17c.

\section{Results and Discussion}

Twelve AMF morphospecies were identified (11 at the species level and 1 at the genus level), distributed in four families (Acaulosporaceae, Archaeosporaceae, Glomeraceae, and Gigasporaceae) and five genera (Table 2). The genera Glomus and Acaulospora, represented by five and three species, respectively, were dominant, accounting together for about $67 \%$ of the total species richness. Ambispora, Gigaspora, Racocetra, and Scutellospora contributed to species richness (33\%) with one species each.

Eight morphospecies were found in the pasture site and nine in the analog agroforestry site. Of these, five morphospecies (Acaulospora mellea, Glomus tortuosum, Glomus macrocarpum, Glomus clavisporum, Glomus microaggregatum) were common to both areas (Table 2). The Sørensen index (0.58) revealed an intermediate similarity (<61.5\%) (Carrenho \& Gomes-da-Costa, 2011) between

Table 2. Relative frequency $\left(F_{i}\right)$ and dominance (Do) of arbuscular mycorrhizal fungal species in pasture and analog agroforestry sites in Seropédica, Rio de Janeiro, Brazil.

\begin{tabular}{lcccc}
\hline \multirow{2}{*}{ Family and species } & \multicolumn{2}{c}{ Pasture } & \multicolumn{2}{c}{ Analog agroforest } \\
\cline { 2 - 5 } & $\boldsymbol{F}_{i}$ & $\mathrm{Do}$ & $\boldsymbol{F}_{i}$ & Do \\
\hline ACAULOSPORACEAE & & & & \\
Acaulospora tuberculata & - & - & 10 & $\mathrm{R}$ \\
Acaulospora mellea & 10 & $\mathrm{R}$ & 20 & $\mathrm{C}$ \\
Acaulospora foveata & 10 & $\mathrm{R}$ & - & - \\
\hline ARCHAEOSPORACEAE & & & & \\
Ambispora leptoticha & - & - & 40 & $\mathrm{VC}$ \\
\hline GLOMERACEAE & & & & \\
Glomus tortuosum & 20 & $\mathrm{C}$ & 20 & $\mathrm{C}$ \\
Glomus macrocarpum & 90 & $\mathrm{D}$ & 90 & $\mathrm{D}$ \\
Glomus clavisporum & 10 & $\mathrm{R}$ & 60 & $\mathrm{D}$ \\
Glomus microaggregatum & 10 & $\mathrm{R}$ & 50 & $\mathrm{VC}$ \\
Glomus glomerulatum & - & - & 60 & $\mathrm{D}$ \\
\hline GIGASPORACEAE & & & & \\
Gigaspora sp. & 10 & $\mathrm{R}$ & - & - \\
Racocetra persica & - & - & 10 & $\mathrm{R}$ \\
Scutellospora scutata & 10 & $\mathrm{R}$ & - & - \\
\hline
\end{tabular}


AMF communities in pasture and analog agroforestry sites. This result might be a reflection of differences in floristic composition, biomass generation, and diversity of functional plant groups between the study sites (Goomaral et al., 2019). In addition, the influence of the different soil chemical and microclimate characteristics of these two systems (Tabela 1) can be considered.

Glomus was dominant and Acaulospora common in both sites, whereas Ambispora was very common in the analog agroforestry site and absent in the pasture site (Table 2). Gigaspora and Scutellospora were rare in the pasture site and Racocetra in the analog agroforestry site. Although there is no specificity between symbionts for the establishment of mycorrhizal association, environmental conditions can influence the presence of host plants and, as a consequence, alter AMF community composition. Thus, some AMF species may be ubiquitous and others rare (Winagraski et al., 2019).

Ambispora leptoticha was common and exclusive to the analog agroforest (Table 2). Its occurrence was significantly ( $p$ $<0.05)$ and positively correlated with soil moisture content $(r=$ $0.51), \mathrm{pH}(r=0.51), \mathrm{Ca}^{2+}(r=0.66)$, and sum of bases $(r=0.46)$; these parameters were highest in the agroforestry site (Camara et al., 2020). On the other hand, A. leptoticha was negatively correlated with soil temperature $(r=-0.49)$ and $\mathrm{K}^{+}(r=-0.49)$, which were lowest in the analog agroforestry site (Camara et al., 2020). A. leptoticha seems to occur more frequently in environments occupied by plant communities with a forestlike structure (such as secondary Atlantic Forest fragments and Eucalyptus plantations) and in areas with low disturbance levels (such as Cerrado regions) (Teixeira et al., 2017). The species is uncommon in areas lacking tree vegetation or with higher levels of anthropogenic disturbances, such as in rocky environments or areas under post-iron mining revegetation with Melinis minutiflora, as seen in the municipality of Sabara, Minas Gerais, Brazil (Teixeira et al., 2017).

G. clavisporum, although detected in both sites, was dominant in the analog agroforestry site and rare in the pasture site (Table 2$)$. It was significantly $(p<0.05)$ and positively correlated with $\mathrm{pH}(r=0.47)$ and $\mathrm{Mg}^{2+}(r=0.52)$. G. clavisporum was among the four species with the lowest frequency $(4-8 \%)$ in an AMF community of 50 species in a highly disturbed semideciduous seasonal forest fragment in Maringá, Paraná, Brazil (Santos \& Carrenho, 2011).

G. glomerulatum was dominant and exclusive to the analog agroforestry site (Table 2 ). Significant $(p<0.05)$ and positive correlations were observed between the species and soil moisture content $(r=0.46), \mathrm{pH}(r=0.70), \mathrm{Ca}^{2+}(r=0.57)$, and sum of bases $(r=0.59)$, and negative correlations with soil temperature $(r=-0.58), \mathrm{K}^{+}(r=-0.57)$, and $\mathrm{H}+\mathrm{Al}(r=-0.63)$, which were lowest in the agroforestry site (Camara et al., 2020). A previous study showed that $G$. glomerulatum spores were more abundant in the rhizosphere of Talipariti elatum and Calophyllum antillanum under shade conditions at 19-23 and $25-30^{\circ} \mathrm{C}$, respectively. Such conditions, as opposed to full sun exposure, imply a high soil moisture content (Torres-Arias et al., 2017).
AMF community complexity (as assessed by mean and total richness and Margalef diversity index) was higher in the analog agroforest (Table 3$)$. There were significant $(p<0.05)$ and positive correlations between mean richness and $\mathrm{pH}$ $(r=0.71), \mathrm{Mg}^{2+}(r=0.56)$, sum of bases $(r=0.61)$, and soil moisture content $(r=0.59)$, as well as significant and negative correlations between mean richness and soil temperature $(r=$ $-0.63)$ and $\mathrm{H}+\mathrm{Al}(\mathrm{r}=-0.62)$. The differences in AMF diversity between land use systems might be associated with biotic and abiotic factors, including environmental conditions, soil fertility, host plant diversity, and agricultural management techniques (Winagraski et al., 2019).

Soil $\mathrm{pH}$ is known to influence the diversity of AMF communities (Kawahara et al., 2016), as it can alter the availability of $\mathrm{Al}, \mathrm{Fe}$, and $\mathrm{Mn}$. In general, the diversity and/ or richness of AMF is higher in less disturbed soils (Schneider et al., 2013) and areas with highly diverse vegetation. For instance, AMF diversity was greater in secondary Atlantic Forest fragments and soil under agroecological coffee cropping (application of green manure and rotation with other crops) than in soil under 30-year coffee monoculture (Prates Junior et al., 2019).

AMF spore abundance, in contrast, was significantly higher in the pasture site (Table 3 ). This result was associated with low soil moisture content and high soil temperature (Table 1) and might have been influenced by the higher density of thin roots in this ecosystem. The stressful microclimatic conditions often observed in pastureland, as opposed to Atlantic Forest sites at different stages of succession, favor the production of AMF survival structures (Silva et al., 2016). Factors such as low anthropogenic interference, high microclimate stability, and soil fertility explain the lower number of spores in the analog agroforestry site (Table 3 ). This pattern was corroborated by significant $(p<0.05)$ negative correlations between spore abundance and soil moisture content $(r=-0.58), \mathrm{pH}(r=-0.72)$, $\mathrm{Ca}^{2+}(r=-0.55), \mathrm{Mg}^{2+}(r=-0.58)$, and sum of bases $(r=-0.69)$ and significant positive correlations with soil temperature $(r=$ $0.67)$ and $\mathrm{H}+\mathrm{Al}(\mathrm{r}=0.50)$.

Table 3. Arbuscular mycorrhizal fungal community attributes, easily extractable glomalin-related soil protein (EE-GRSP), weighted mean diameter (WMD), light-fraction organic matter (LF-OM), particulate organic carbon (POC), and mineralassociated organic carbon (MAOC) in pasture and analog agroforestry sites in Seropédica, Rio de Janeiro, Brazil.

\begin{tabular}{lcc}
\hline \multicolumn{1}{c}{ Parameter } & Pasture & $\begin{array}{c}\text { Analog } \\
\text { agroforest }\end{array}$ \\
\hline Mean richness & $1.7 \mathrm{~B}$ & $3.6 \mathrm{~A}$ \\
Total richness & 8.0 & 9.0 \\
Margalef diversity index & 1.08 & 2.45 \\
Spore abundance (spores $\left.50 \mathrm{~cm}^{3}\right)$ & $649 \mathrm{~A}$ & $26 \mathrm{~B}$ \\
EE-GRSP $\left(\mathrm{mg} \mathrm{g}^{-1}\right)$ & $1.69 \mathrm{~A}$ & $1.22 \mathrm{~B}$ \\
WMD $\left(\mathrm{mm}^{-}\right)$ & $3.64 \mathrm{~B}$ & $4.29 \mathrm{~A}$ \\
LF-OM $\left(\mathrm{g}^{-1}\right.$ & $0.06 \mathrm{~A}$ & $0.06 \mathrm{~A}$ \\
POC $\left(\mathrm{g} \mathrm{kg}^{-1}\right)$ & $3.05 \mathrm{~A}$ & $2.35 \mathrm{~A}$ \\
MAOC $\left(\mathrm{g} \mathrm{kg}^{-1}\right)$ & $25.03 \mathrm{~A}$ & $22.97 \mathrm{~A}$ \\
\hline
\end{tabular}

Means within rows followed by the same letter are not significantly different $(p<0.05)$ according to the parametric Bonferroni test or the nonparametric Mann-Whitney test (spore abundance). 
EE-GRSP was highest in the pasture site (Table 3) and followed the same pattern of correlations observed for spore abundance. However, spore abundance and EE-GRSP were not significantly correlated. EE-GRSP was significantly and negatively correlated with species richness $(r=-0.50)$. A previous report found a positive correlation between EE-GRSP and spore abundance in areas with low degrees of disturbance; in such cases, high glomalin production is associated with the maintenance of the hyphal network in the soil (Fokom et al., 2012).

A significant $(p<0.05)$ and positive correlation was observed between EE-GRSP and total organic carbon $(r=0.70)$, $\mathrm{P}(\mathrm{r}=0.80), \mathrm{K}^{+}(\mathrm{r}=0.54), \mathrm{H}+\mathrm{Al}(\mathrm{r}=0.71)$, and soil temperature $(r=0.67)$. However, a significant and negative correlation was found between EE-GRSP and $\mathrm{pH}(r=-0.63), \mathrm{Mg}^{2+}(r=-0.65)$, and sum of bases $(r=-0.62)$. Similar patterns were observed in other studies, with significant positive correlations between glomalin and total organic carbon, $\mathrm{P}$, and $\mathrm{K}^{+}$(Kumar et al., 2018) and significant negative correlations between EE-GRSP and $\mathrm{pH}$ (Kumar et al., 2018).

Under conditions of high soil acidity, as occurred in the pasture site, high concentrations of glomalin can be attributed to two factors. The first is the lower degradation rate of glomalin at low soil $\mathrm{pH}$; such a condition is not favorable to the activity of microorganisms that participate in protein decomposition, such as Actinobacteria (Lima et al., 2013). The second refers to the greater root colonization by AMF in low $\mathrm{pH}$ soil, a fact that is associated with higher AMF activity and, consequently, greater production of glomalin (Ríos-Ruiz et al., 2019).

Soil aggregate stability (expressed as weighted mean diameter) was highest in the analog agroforestry site (Table 3 ), probably because of the greater richness of AMF and plant species. As a result, hyphae are more abundant in the soil, contributing physically and biochemically (glomalin production) to soil aggregation (Winagraski et al., 2019). This effect was observed despite the fact that EE-GRSP levels were higher in the pasture site (Table 3). Aggregate stability was also likely associated with the higher abundance and diversity of soil arthropods in the analog agroforest (Camara et al., 2020). This diverse group of organisms comprises ecosystem engineers, whose excrements compose soil aggregates and contribute to stabilization, favoring the regulation of soil porosity, density, and other properties (Coyle et al., 2017). Stable aggregates are crucial for good soil structure. Porous spaces allow root development, air and water circulation, and survival of soil arthropods (Salton et al., 2008).

Soil organic matter fractions (light-fraction organic matter, particulate organic carbon, and mineral-associated organic carbon) did not differ between sites, as assessed by univariate analysis (Table 3). Similarly, principal component analysis showed that these attributes contributed little (factor loadings $<0.6$ ) to the variation between pasture and analog agroforestry sites (Figure 1). Principal components 1 and 2 (PC1 and PC2) accounted for 39.55 and $16.59 \%$ of the variance in the dataset, respectively.
Of the variables assessed in this study, those related to soil microbiota (spore abundance, AMF species richness, and EE-GRSP) contributed the most to the distance between sites along the PC1 axis (factor loadings $\geq 0.70$ ). Spore abundance and EE-GRSP were more associated with the pasture site, as were chemical properties $\left(\mathrm{P}, \mathrm{K}^{+}, \mathrm{H}+\mathrm{Al}\right)$ and soil temperature (right upper and lower quadrants) (factor loadings $\geq 0.70$ ).

On the other hand, species richness, moisture, $\mathrm{pH}, \mathrm{Mg}^{2+}$, and sum of bases were correlated with the analog agroforestry site (upper and lower left quadrants). Thus, the analysis revealed associations (positive or negative) between AMFrelated parameters (richness, diversity, and EE-GRSP) and soil physical and chemical properties and microclimate (water content and temperature), corroborating the results. AMF served as indicators of the effects of 11 years of agroforestry management on soil quality.

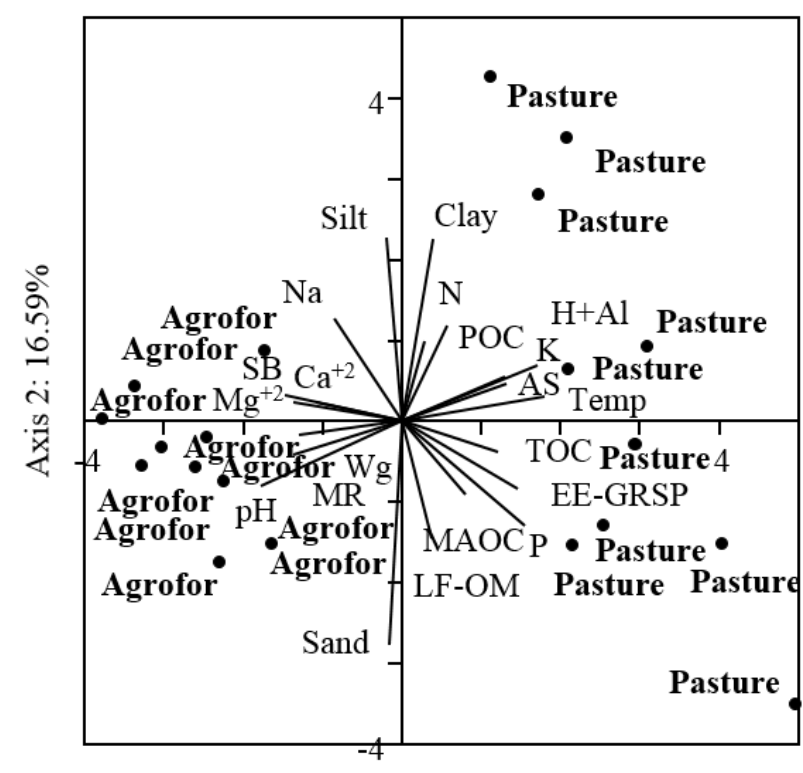

Axis $1: 39.55 \%$

$\mathrm{MR}$, mean richness; $\mathrm{W}_{\mathrm{g}}$, gravimetric moisture; $\mathrm{POC}$, particulate organic carbon; $\mathrm{SA}$, spore abundance; Temp, temperature; TOC, total organic carbon; EE-GRSP, easily extractable glomalin-related soil protein; MAOC, mineral-associated organic carbon; LF-OM, lightfraction organic matter; SB, sum of bases.

Figure 1. Principal component analysis of soil chemical, physical, and microbiological properties at the $0-5 \mathrm{~cm}$ depth in sites under pasture and analog agroforestry systems (agrofor) in Seropédica, Rio de Janeiro, Brazil.

\section{Conclusions}

AMF richness and diversity were influenced differently by the chemical, physical and microclimatic properties of soils under pasture and agroforestry compared with AMF spore abundance. AMF species richness, diversity, and aggregate stability were higher in the analog agroforestry system, where the species A. leptoticha, G. clavisporum, and $G$. glomerulatum were found to occur exclusively. These parameters were positively associated with $\mathrm{pH}$, sum of bases, and soil moisture. Spore abundance and EE-GRSP levels were higher in the pasture site, attributed to the higher soil 
temperature, $\mathrm{P}, \mathrm{K}^{+}$, and $\mathrm{H}+\mathrm{Al}$. EE-GRSP correlated positively with total organic carbon. Physical fractions of organic matter did not vary significantly between the study sites. Aggregate stability was greater in soil under analog agroforest than pasture. Thus, analog agroforest changes the soil physical and microbiological attributes evaluated, and the microbiological attributes are influenced by $\mathrm{pH}, \mathrm{Mg}^{+2}, \mathrm{~K}^{+}, \mathrm{SB}, \mathrm{P}, \mathrm{H}+\mathrm{Al}$, soil moisture and TOC.

\section{Compliance with Ethical Standards}

Author contributions: Conceptualization: RC, MGP; Data curation: CFS, RC, GLS, GSA, CSS, HGF; Formal analysis: CFS, RC; Funding acquisition: MGP, EMRS; Investigation: CFS, GLS, GSA, CSS, HGF; Methodology: CFS, MGP, RC; Project administration: RC; Resources: MGP, EMRS; Supervision: RC, MGP; Visualization: CFS, RC, MGP; Writing - original draft: CFS, RC; Writing - review \& editing: MGP, EMRS

Conflict of interest: The authors declare that there is no possible conflict of interest (professional or financial) that may influence the article.

Funding: Brazilian Federal Agency for Support and Evaluation of Graduate Education (CAPES, finance code 001) and Carlos Chagas Filho Foundation for Research Support of the State of Rio de Janeiro (FAPERJ).

\section{Literature Cited}

Anderson, J.M.; Ingram, J.S.I. Tropical soil biology and fertility: a handbook of methods. Wallingford: CAB International, 1989. 240p.

Balin, N. M.; Ziech, A. R. D.; Oliveira, J. P. M. de; Girardello, V. C.; Stumpf, L.; Conceição, P. C. Frações da matéria orgânica, índice de manejo do carbono e atributos físicos de um latossolo vermelho sob diferentes sistemas de uso. Scientia Agraria, v.18, n. 3, 85-94. https://doi.org/10.5380/rsa.v18i3.53114.

Camara, R.; Santos, G.L.; Silva, C.S.; Silva C.F.; Aguiar, G.S.; Pereira, M.G. Physical, chemical, and biological soil attributes under analog agroforestry system and pasture sites. Floresta, v.50, n.1, p.887-896, 2020. https://doi.org/10.5380/rf.v50i1.57476.

Cambardella, C.A.; Elliott, E.T., Particulate soil organic matter changes across a grassland cultivation sequence. Soil Science Society of America Journal, v.56, n.3, p.777-783, 1992. https://doi. org/10.2136/sssaj1992.03615995005600030017x.

Carrenho, R.; Gomes-da-Costa, S.M. Environmental degradation impact on native communities of arbuscular mycorrhizal fungi in an urban fragment of semideciduous plateau forest. Acta Botanica Brasilica v.25, n.2, p.373-379, 2011. https://doi. org/10.1590/S0102-33062011000200013.

Costa, E.M.; Silva, H.F.; Ribeiro, P.R.A. Matéria orgânica do solo e o seu papel na manutenção e produtividade dos sistemas agrícolas. Enciclopédia Biosfera, v. 9, n. 17, p. 1842-1860, 2013. http:// www.conhecer.org.br/enciclop/2013b/CIENCIAS\%20AGRARIAS/ materia\%20organica.pdf. 02 Aug. 2020.
Coyle, D.R.; Nagendra, U.J.; Taylor, M.K.; Campbell, J.H.; Cunard, C.E.; Joslin, A.H.; Mundepi A.; Phillips, C.A.; Callaham Jr., M.A. Soil fauna responses to natural disturbances, invasive species, and global climate change: current state of the science and a call to action. Soil Biology \& Biochemistry, v.110, p.116-133, 2017. https://doi.org/10.1016/j.soilbio.2017.03.008.

Donagemma, G.K.; Campos, D.V.B.; Calderano, S.B.; Teixeira, W.G.; Viana, J.H.M. Manual de métodos de análise de solos. Rio de Janeiro: Embrapa Solos, 2011. 230p.

Fokom, R.; Adamou, S.; Teugwa, M.C.; Boyogueno, A.D.B.; Nana, W.L.; Ngonkeu, M.E.L.; Tchameni, N.S.; Nwaga, D.; Tsala Ndzomo, G.; Amvam Zollo, P.H. Glomalin related soil protein, carbon, nitrogen and soil aggregate stability as affected by land use variation in the humid forest zone of south Cameroon. Soil and Tillage Research, v.120, p.69-75, 2012. https://doi. org/10.1016/j.still.2011.11.004.

Gerdermann, J. W.; Nicolson, T. H. Spores of mycorrhizal Endogone species extracted from soil by wet sieving and decanting. Transactions of the British Mycological Society, v.46, n.2, p.235244, 1963. https://doi.org/10.1016/S0007-1536(63)80079-0.

Goomaral, A.; Yamato, M.; Kusakab, R.; Undarmaa, J.; Yamanaka, N.; Tanigicho, T. Effects of livestock grazing intensity on soil arbuscular mycorrhizal fungi and glomalin-related soil protein in a mountain forest steppe and a desert steppe of Mongolia. Landscape and Ecological Engineering, 2019. https://doi. org/10.1007/s11355-019-00399-2.

Kawahara, A.; An, G.; Miyakawa, S.; Sonoda, J.; Ezawa, T. Nestedness in arbuscular mycorrhizal fungal communities along soil ph gradients in early primary succession: acid-tolerant fungi are ph generalists. Plos One v.11, n.10, e0165035, 2016. https:// doi.org/10.1371/journal.pone.0165035.

Kumar, S.; Singh, A.K.; Ghosh, P. Distribution of soil organic carbon and glomalin related soil protein in reclaimed coal mine-land chronosequence under tropical condition. Science of The Total Environment, v.625, p.1341-1350. 2018. https://doi. org/10.1016/j.scitotenv.2018.01.061.

Lima, F.S.; Soares, A.C.F.; Sousa, C.S. Ocorrência e atividade de fungos micorrízicos arbusculares em plantios de eucalipto (Eucalyptus sp.) no litoral norte da Bahia, Brasil. Revista Árvore, v.37, n.2, p.245-255, 2013. https://doi.org/10.1590/s010067622013000200006.

Liu, H.; Wang, X.; Lianga, C.; Aid, Z.; Wu, Y.; Xu, H.; Xue, S.; Guobin, L. Glomalin-related soil protein affects soil aggregation and recovery of soil nutrient following natural revegetation on the Loess Plateau. Geoderma, v.357, 113921, 2020. https://doi. org/10.1016/j.geoderma.2019.113921.

Martins, E.M.; Silva, E.R.; Campello, E.F.C.; Resende, A.S.; Lima, S.S.; Nobre, C.P.; Correia, M.E.F.; Resende, A.S. O uso de sistemas agroflorestais diversificados na restauração florestal na Mata Atlântica. Ciência Florestal, v.29, n.2, p.632-648, 2019. https:// doi.org/10.5902/1980509829050.

Oehl, F.; Sieverding, E.; Palenzuela, J.; Ineichen, K.; Silva, G.A. Advances in Glomeromycota taxonomy and classification. IMA Fungus, v.2, n.2, p.191-199, 2011. https://doi.org/10.5598/ imafungus.2011.02.02.10. 
Prates Júnior, P.; Moreira, B.C.; Silva, M.C.S.; Veloso, T.G.R.; Stürmer, S.L.; Fernandes, R.B.A.; Mendonça, E.S.; Kasuya, M.C.M. Agroecological coffee management increases arbuscular mycorrhizal fungi diversity. PLoS ONE, v.14, n.1 e0209093, 2019. https://doi.org/10.5598/ imafungus.2011.02.02.1010.1371/journal.pone.0209093.

Ríos-Ruiz, W.F.; Barrios-López, L.; Rojas-García, J.C.; Valdez-Nuñez, R.A. Mycotrophic capacity and diversity of native arbuscular mycorrhizal fungi isolated from degraded soils. Scientia Agropecuaria. v.10, n.1, p.99-108, 2019. https://doi.org/10.17268/sci.agropecu.2019.01.11.

Salton, J.C.; Mielniczuk, J.; Bayer, C.; Boeni, M.; Conceição, P.C.; Fabrício, A.C.; Macedo, M.C.M.; Broch, B.L. Agregação e estabilidade de agregados do solo em sistemas agropecuários em Mato Grosso do Sul. Revista Brasileira de Ciência do Solo v.32, n.1, p.11-21, 2008. https://doi.org/10.1590/S0100-06832008000100002.

Santos, F.E.F.; Carrenho, R. Diversidade de fungos micorrízicos arbusculares em remanescente florestal impactado (Parque Cinquentenário - Maringá, Paraná, Brasil). Acta Botanica Brasilica, v.2, n.25, p. 508-516, 2011. https://doi.org/10.1590/S010233062011000200026.

Schneider, J.; Labory, C.R.G.; Rangel, W.M.; Alves, E.; Guilherme, L.R.G. Anatomy and ultrastructure alterations of Leucaena leucocephala (Lam.) inoculated with mycorrhizal fungi in response to arseniccontaminated soil. Journal of Hazardous Materials, v.262, p.12451258, 2013. https://doi10.1016/j.jhazmat.2012.05.091.

Silva, C.F.; Pereira, M.G.; Santos, V.L.; Miguel, D.L.; Silva, E.M.R. Fungos micorrízicos arbusculares: composição, comprimento de micélio extrarradicular e glomalina em áreas de mata atlântica, Rio de Janeiro. Ciência Florestal, v.26, n.2, p.419-433, 2016. https://doi. org/10.5902/1980509822743.

Singh, A.K.; Rai, A.; Pandey, V.; Singh, N. Contribution of glomalin to dissolve organic carbon under different land uses and seasonality in dry tropics. Journal of Environmental Management, v.192, p.142149, 2017. https://doi.org/10.1016/j.jenvman.2017.01.041.

Souza, M.C.S.; Piña-Rodrigues, F.C.M. Desenvolvimento de espécies arbóreas em sistemas agroflorestais para recuperação de áreas degradadas na Floresta Ombrófila Densa, Paraty, RJ. Revista Árvore, v.37, n.1, p.89-98, 2013. https://doi.org/10.1590/S010067622013000100010.
Souza, M.C.S.; Piña-Rodrigues, F.C.M.; Casagrande, J.C.; Silva, S.F.; Scoriza, R.N. Funcionalidade ecológica de sistemas agroflorestais biodiversos: uso da serapilheira como indicador da recuperação de áreas de preservação permanente. Floresta, v. 46, n. 1, p. 75 82, 2016. https://doi.org/10.5380/rf.v46i1.34991.

Teixeira, A.F.S.; Kemmelmeier, K.; Marascalchi, M.N.; Stürmer, S.L.; Carneiro, M.A.C.; Moreira, F.M.S. Comunidades de fungos micorrízicos arbusculares em área de mineração e seu entorno: Potencial de inóculo, densidade e diversidade de esporos relacionados a atributos do solo. Ciência e Agrotecnologia, v.41, n.5, p.511-525, 2017. https://doi.org/10.1590/141370542017415014617.

Torres-Arias, Y.; Fors, R. O.; Nobre, C.; Gómez, E. F.; Berbara, R. L. L. Production of native arbuscular mycorrhizal fungi inoculum under different environmental conditions. Brazilian Journal of Microbiology, v.48, n.1, p.87-94, 2017. https://doi.org/10.1016/j. bjm.2016.10.012.

Winagraski, E.; Kaschuk, G.; Monteiro, P.H.R.; Auer, G.; Higa, A.R. Diversity of arbuscular mycorrhizal fungi in forest ecosystems of brazil: a review. Cerne, v.25, n.1, p.25-35. 2019. https://doi.org/1 $0.1590 / 01047760201925012592$.

Wright, S.F.; Franke-Snyder, M.; Morton, J.B.; Upadhyaya, A. Timecourse study and partial characterization of a protein on Hyphae of arbuscular mycorrhizal fungi during active colonization of roots. Plant and Soil, v.181, p.193-203, 1996. https://doi. org/10.1007/BF00012053.

Zangaro, W.; Ansanelo, A.P.; Lescano, L.E.A.M.; Alves, R.C.; Rondina, A.B.L.; Nogueira, M.A. Infection intensity, spore density and inoculum potential of arbuscular mycorrhizal fungi decrease during secondary succession in tropical Brazilian ecosystems. Journal of Tropical Ecology, v.28, p.453-462, 2012. https://doi. org/10.1017/S0266467412000399.

Zhang, Y.; Gui, L.D.; Liu, R.J. Survey of arbuscular mycorrhizal fungi in deforested and natural forest land in the subtropical region of Dujiangyan, southwest China. Plant and Soil, v.261, p.257-263. 2004. https://doi.org/10.1023/B:PLSO.0000035572.15098.f6. 